\title{
HUBUNGAN KADAR UREA DENGAN HOMOCITRULINE PADA GAGAL GINJAL TERMINAL
}

\author{
Verbrini Rifnayeni, Ellyza Nasrul, Hanifah Maani, Zelly Dia Rofinda
}

\begin{abstract}
Abstrak
Peningkatan kadar urea (uremia) ditemukan pada gagal ginjal terminal.Tujuan penelitian ini adalah untuk mengetahui hubungan kadar urea dengan homocitruline pada pasien gagal ginjal terminal. Penelitian ini menggunakan rancangan analitik observasional cross sectional pada 23 pasien gagal ginjal terminal yang menjalani Hemodialisis di RSUP. Dr. M. Djamil Padang. Penelitian berlangsung sejak Februari hingga Oktober 2014. Subjek diambil dengan consecutive sampling. Sampel serum diperiksa kadar ureanya dengan metode enzimatik glutamate dehidrogenase. Homocitruline diperiksa secara indirek ELISA. Analisis statistik menggunakan uji korelasi Pearson. Hasil penelitian ini menunjukkan jumlah subjek sebanyak $52,2 \%$ perempuan

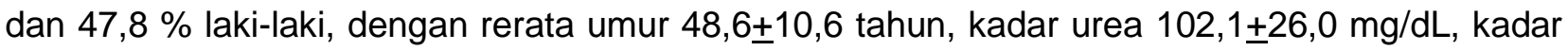
homocitruline $1,2 \pm 0,7 \mathrm{ng} / \mathrm{mL}$. Penelitian ini menunjukan ada korelasi negatif yang tidak signifikan $(\mathrm{r}=-0.2, \mathrm{p}>0.05)$ antara kadar urea dengan homocitruline pada pasien gagal ginjal terminal.
\end{abstract}

Kata Kunci: urea, homocitruline, gagal ginjal terminal

\begin{abstract}
Increase urea (uremia) can be found at end stage renal disease. This study was know correlation between urea with homocitruline level at end stage renal disease. This is cross sectional observational analytic study at 23 patients with end stage renal disease on hemodyalisis in $M$. Djamil Hospital, Padang, from February 2014 until October 2014, with consecutive sampling. Urea level was determined from serum sample by kinetic enzymatic glutamate dehydrogenase, and homocitruline by indirect ELISA. Statistical analysis was done by pearson correlation. The research showed that $52.2 \%$ are women and $47.8 \%$ are men with mean age is $48.6 \pm 10.6$ years old, mean urea level is $102.1 \pm 26.0 \mathrm{mg} / \mathrm{dL}$, homocitruline level is $1.2 \pm 0.7 \mathrm{ng} / \mathrm{mL}$. The correlation between urea level and homocitruline was not significant $(r=-0.2, p>0.05)$. There was negative weak correlation between urea level and homocitruline at end stage renal disease.
\end{abstract}

Key Words: urea, homocitruline, end stage renal disease

Afiliasi penulis : Program Pendidikan Dokter Spesiaslis Patologi Klinik Fakultas Kedokteran Universitas Andalas, Korespondensi : Verbrini Rifnayeni, Email: verbrinirifnayeni@ymail.com , HP: 085376167431 


\section{PENDAHULUAN}

Gagal ginjal terminal merupakan suatu keadaan dengan tanda dan gejala gagal ginjal berupa uremia. Uremia merupakan peningkatan kadar urea plasma. Gangguan ginjal ini memerlukan terapi pengganti ginjal, seperti dialisis atau transplantasi ginjal tanpa memperhatikan tingkat laju filtrasi glomerulus. ${ }^{1}$

Urea adalah hasil akhir metabolisme protein yang dikeluarkan melalui ginjal dan merupakan hampir separuh zat terlarut dalam urin. Urea akan diurai secara spontan menjadi sianat dan ammonia. Sianat secara cepat diubah menjadi bentuk reaktif, yaitu asam isosianat. Asam isosianat akan bereaksi dengan grup fungsional bebas seperti amino, thiol, karboksil atau fenol sehingga terjadi karbamilasi protein (Gambar 1.). ${ }^{2}$

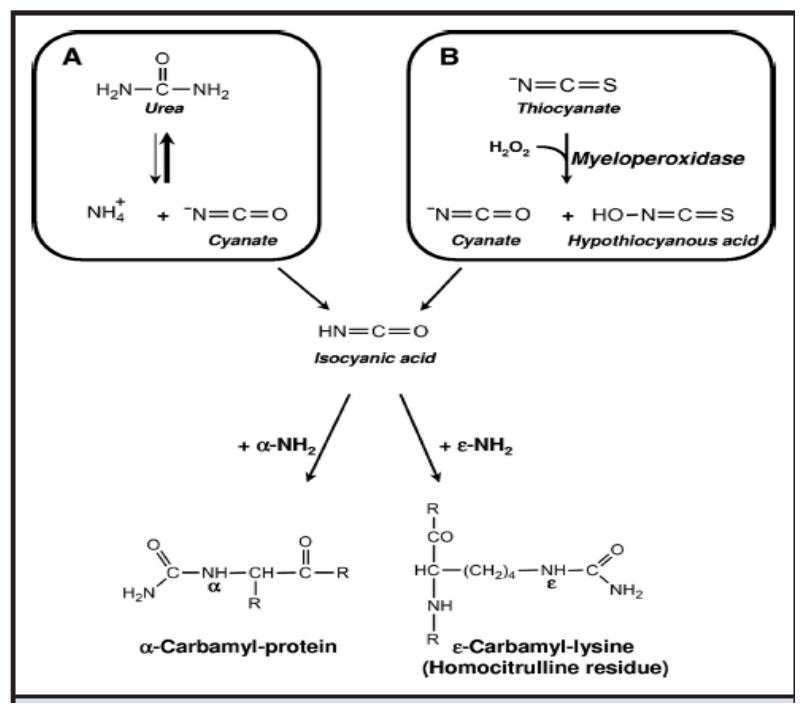

Gambar 1. Pembentukan Homocitruline ${ }^{2}$

Selain dari dekomposisi urea, pembentukan sianat juga dapat berasal dari metabolisme thiosianat terutama pada pasien non uremia. Thiosianat dengan adanya enzim mieloperoksidase dan hidrogen peroksidase sebagai ko- reaktan, akan mengalami oksidasi sehingga dihasilkan sianat dan asam hipothiosianat. ${ }^{2,3}$. Mieloperoksidase merupakan enzim yang berhubungan dengan inflamasi dan stres oksidatif. Enzim ini banyak diekspresikan dalam granul azurofilik leukosit terutama neutrofil dan monosit. Enzim ini dilepaskan oleh leukosit pada keadaan inflamasi. Peningkatan mieloperoksidase akan meningkatkan perubahan thiosianat menjadi sianat. ${ }^{3}$

Karbamilasi protein adalah suatu modifikasi posttranslasi protein yang akan menyebabkan perubahan struktur dan fungsi protein. Homocitruline merupakan salah satu hasil karbamilasi protein, reaksi antara asam isosianat dengan grup $\varepsilon$ amino. Pemeriksaan homocitruline merupakan pemeriksaan yang spesifik dan sensitif, serta lebih menggambarkan laju karbamilasi protein. ${ }^{2}$

Karbamilasi protein diduga terlibat pada progresivitas beberapa penyakit seperti gagal ginjal terminal, proses aterosklerosis, dan kejadian kardiovaskular. Karbamilasi protein pada pasien gagal ginjal terminal merupakan faktor yang akan memperburuk penyakit seperti menimbulkan kerusakan sel tubulus dan meningkatkan fibrosis peritubular, memperberat anemia karena hemolisis dan terjadi resistensi rekombinan eritropoetin. Karbamilasi protein diduga juga berperan pada proses aterosklerosis melalui karbamilasi LDL dan HDL. ${ }^{2,4,5,6,7}$

Penelitian yang dilakukan oleh Balion et al., (1998) dan Koeth et al., (2013) di California menemukan adanya kadar homocitruline yang lebih tinggi secara bermakna pada pasien yang menjalani hemodialisis rutin dibanding- 
kan dengan kelompok kontrol. Penelitian lain yang dilakukan oleh Ok et al., (2005) juga menemukan adanya peningkatan bermakna kadar homocitruline pada pasien gagal ginjal yang menjalani hemodialisis dibandingkan kelompok kontrol (42 $\pm 4 \mathrm{nmol}$ homocitruline/mg protein vs $12 \pm 3 \mathrm{nmol}$ homocitruline/mg protein, $p<0,001)$. Sementara itu, penelitian Balion et al., (1998) menemukan adanya hubungan antara kadar urea predialisis dengan karbamilasi protein pada pasien hemodialisis yang bervariasi dengan $r$ : 0,$48 ; 0,77 ; 0,66$; 0,26; dan 0,08.

Berdasarkan paparan tersebut, penelitian mengenai kadar urea dan homocitruline pada pasien gagal ginjal penting untuk dilakukan. Tujuan penelitian ini untuk mengetahui hubungan kadar urea dengan homocitruline pada pasien gagal ginjal terminal.

\section{METODE}

Penelitian ini merupakan penelitian observasional analitik dengan rancangan potong lintang pada 23 pasien gagal ginjal terminal yang menjalani hemodialisis. Penelitian dilakukan di RSUP. Dr. M. Djamil Padang dari Februari 2014 hingga Oktober 2014. Subjek penelitian ini diambil dengan metode consecutive sampling. Kriteria eksklusi subjek adalah pasien dengan neutrofilia, pasien sirosis, dan perokok. Sampel serum diperiksa kadar urea dengan metode enzimatik glutamate dehidrogenase, sedangkan homocitruline diperiksa secara indirek ELISA. Analisis statistik dilakukan dengan menggunakan uji korelasi Pearson.

\section{HASIL DAN PEMBAHASAN}

Karakteristik dasar subjek penelitian berdasarkan jenis kelamin, umur, kadar urea, lamanya hemodialisis, dan kadar homocitruline dipaparkan pada tabel 1. Pada tabel 1 terlihat bahwa subjek penelitian terbanyak adalah perempuan $(52,2 \%)$. Sementara itu, rerata umur subjek penelitian adalah 48,6 \pm 10,6 tahun dengan rentang umur 31- 68 tahun. Adapun rerata kadar urea pada pasien yang menjalani hemodialisis adalah 102,1 $\pm 26,0 \mathrm{mg} / \mathrm{dL}$, dan kadar homocitruline adalah 1,2 $\pm 0,7 \mathrm{ng} / \mathrm{mL}$.

Penelitian ini menemukan bahwa sebanyak 25,2\% dari 23 pasien gagal ginjal terminal yang menjalani hemodialisis adalah perempuan. Hasil ini berbeda dengan penelitian yang dilakukan Saat et al., (2011) di Kuala Lumpur yang hasilnya menunjukkan sebagian besar yang mendapatkan gagal ginjal terminal adalah laki-laki (59\%). Penelitian Saryono dan Handoyo (2006) di Purwokerto juga menemukan bahwa $67 \%$ subjek yang mengalami gangguan gagal ginjal terminal adalah laki-laki.

Terkait temuan tersebut, bahwa perempuan lebih banyak mengalami gagal ginjal terminal, diduga karena uretra wanita lebih pendek daripada lakilaki yang menyebabkan mereka lebih mudah mengalami infeksi sekitar enam kali dibandingkan laki-laki. Secara epidemiologi penyebab gagal ginjal kronis di Indonesia adalah glomerulonefritis, diabetes melitus, serta obstruksi dan infeksi. ${ }^{12}$ Kemungkinan lain perempuan mempunyai jumlah glomerulus yang lebih sedikit sekitar 10\%-15\% dibanding laki-laki. ${ }^{13}$ 
Tabel 1. Karakteristik Dasar Subjek Penelitian

\begin{tabular}{|c|c|c|c|}
\hline \multirow[t]{2}{*}{ Karakteristik } & \multicolumn{3}{|c|}{ Pasien gagal ginjal terminal } \\
\hline & $\mathrm{n}(\%)$ & rerata + SD & Nilai tengah (rentang) \\
\hline 1. Jenis kelamin & & & \\
\hline $\begin{array}{l}\text { Laki-laki } \\
\text { Peremnuan }\end{array}$ & $11(47,8)$ & & \\
\hline Perempuan & $12(52,2)$ & & \\
\hline
\end{tabular}

2. Umur (tahun)

3. Lamanya Hemodialisis (bulan)

4. Urea $(\mathrm{mg} / \mathrm{dL})$

5. Homocitruline $(\mathrm{ng} / \mathrm{mL})$

Rerata umur subjek penelitian adalah 48,6 \pm 10,6 tahun dengan rentang umur 31- 68 tahun. Penelitian Chijioke et al., di Nigeria mendapatkan rerata umur 41,6 \pm 16,3 tahun. Penelitian Saryono dan Handoyo di Purwokerto menemukan bahwa prevalensi tertinggi pasien yang menjalani hemodialisis ada pada rentang umur antara 36-50 tahun. ${ }^{11}$ Prevalensi GGK pada negara maju meningkat dengan bertambahnya umur dan insidensi tertinggi pada dekade tujuh dan delapan. Perbedaan umur insidensi GGK di negara berkembang (dekade tiga dan empat) mungkin berhubungan dengan faktor genetik, faktor sosial ekonomi, dan pola penyakit penyebab GGK. ${ }^{14}$ Pada usia muda gagal ginjal jarang terjadi, namun dapat terjadi akibat dehidrasi yang kronis maupun zat nefrotoksis. Konsumsi makanan atau minuman yang mengandung zat nefrotoksik juga akan mempercepat terjadinya perusakan sel-sel ginjal. Pada usia dewasa tua dan manula, secara anatomis kemampuan pertumbuhan sel-sel ginjal mulai menurun dan mulai terjadi kemunduran fungsi sel ginjal. ${ }^{11}$

Rerata kadar urea yang didapatkan pada penelitian ini lebih tinggi dari
$48,6 \pm 10,6$

$102,1 \pm 6,0$

$1,2 \pm 0,7$

nilai rujukan (19-44 mg/dL), yaitu 102,1 \pm $26,0 \mathrm{mg} / \mathrm{dL}$. Hal ini juga didapatkan oleh Saryono dan Handoyo di Purwokerto pada pasien yang menjalani hemodialisis sekitar 151,11 $\pm 63,29 \mathrm{mg} / \mathrm{dL}$. Di sisi lain, penelitian Todd et al., mendapatkan rerata BUN adalah 24,5 \pm 10,6 mg/dL. Salah satu fungsi ginjal adalah mensekresikan produk akhir nitrogen dari metabolisme protein terutama urea, asam urat, dan kreatinin. Pada gagal ginjal terminal terjadi penurunan fungsi ginjal, sehingga terjadi gangguan sekresi yang akan menyebabkan retensi produk akhir nitrogen, salah satunya peningkatan kadar urea. ${ }^{15}$

Uji normalitas menggunakan uji kolmogorov-Smirnov Z menunjukkan bahwa distribusi data kadar urea dan homocitruline terdistribusi normal dengan p> 0,05. Setelah dilakukan uji statistic dengan menggunakan korelasi Pearson didapat korelasi negatif yang tidak signifikan atau tidak ada hubungan secara statistik antara kadar urea dengan homocitruline pada pasien gagal ginjal terminal $(r=-0,2 ; p>0,05)$ (Gambar 2).

Hubungan kadar urea dengan homocitruline yang diperiksa secara ELISA 
pada penelitian ini didapatkan korelasi negatif tidak signifikan $(r=-0,02 ; p>$ $0,05)$. Dengan kata lain, secara statistik tidak ada hubungan antara kedua variabel tersebut.

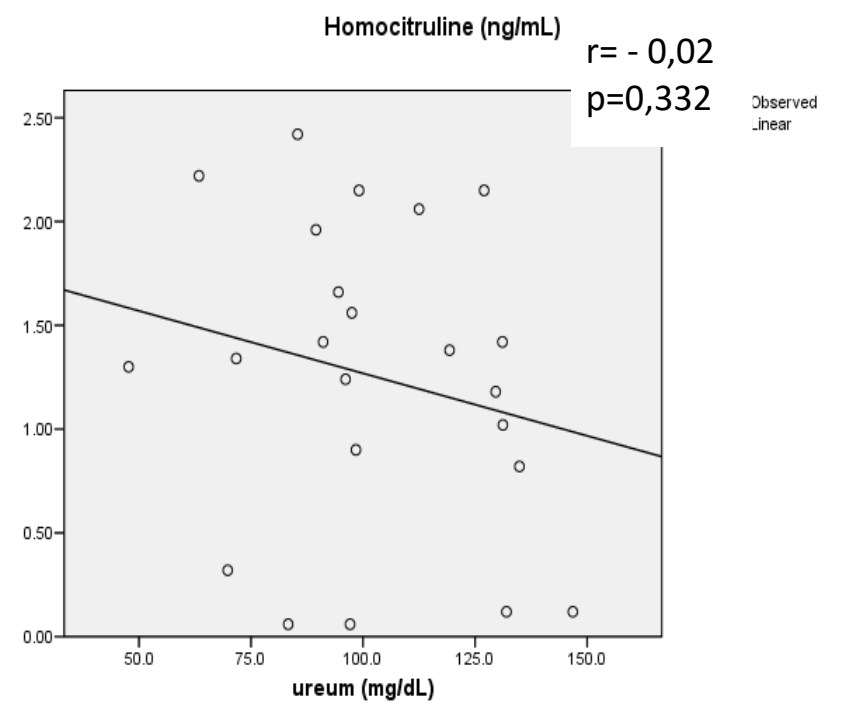

Gambar 2. Kurva Linear Korelasi Kadar Urea dengan Homocitruline pada Pasien Gagal Ginjal Terminal

Sepengetahuan peneliti belum ada penelitian yang memeriksa hubungan antara kadar urea dengan homocitruline pada pasien gagal ginjal terminal. Penelitian Balion et al., memperlihatkan hubungan kadar urea predialisis dengan karbamilasi protein yang diperiksa dengan kolorimetrik dan didapatkan hubungan yang tidak konstan. Penelitian lain yang dilakukan oleh Wang et al., tentang pemeriksaan homocitruline dengan mass spektrofotometri (MS). Penelitian yang dilakukan oleh Koeth et al., tentang homocitruline pada pasein ESRD dengan metode HPLC dan mass spektrofotometri, mendapatkan kadar homocitruline 0,179 \pm 0,136-0,220 $\mathrm{mmol} / \mathrm{mol}$ Lys. Penelitian yang dilakukan Pietrement et al., mendapatkan hubungan positif antara kadar urea dan homocitruline pada tikus, pemeriksaan homocitruline dengan HPLC dan MS. Pemeriksaan dengan HPLC sampel diekstraksi dan dimurnikan dengan asam hidroklorida. Adanya perbedaan metode pemeriksaan pada penelitian ini dengan penelitian lain, kemungkinan yang menyebabkan hasilnya berbeda jauh.

Perbedaan ini mungkin disebabkan oleh derajat keasaman $(\mathrm{pH})$. Secara teori dikatakan bahwa karbamilasi oleh asam isosianat tergantung pada $\mathrm{pH}$. $\mathrm{pH}$ 8,5-9,5 merupakan $\mathrm{pH}$ optimum untuk karbamilasi lysine sehingga terbentuk homocitruline. Sedangkan pada $\mathrm{pH}$ rendah karbamilasi protein pada grup $\alpha$ amino lebih mungkin terjadi. ${ }^{18} \mathrm{Hal}$ ini merupakan kekurangan penelitian ini karena tidak memeriksa $\mathrm{pH}$.

Hal lain yang kemungkinan menyebabkan perbedaan hasil tersebut adalah kompetitif dengan asam amino, karena asam amino berfungsi sebagai scavenger karbamilasi sehingga menghambat karbamilasi protein. Dengan demikian, defisiensi asam amino mungkin berperan meningkatkan karbamilasi protein pada pasien hemodialisis. Peneliti pada penelitian ini tidak menilai kadar asam amino pasien apakah terjadi defisiensi atau tidak sehingga mempengaruhi kadar homocitruline. ${ }^{19}$

\section{SIMPULAN}

Penelitian ini menunjukkan bahwa pasien yang mengalami gagal ginjal terminal lebih banyak berjenis kelamin perempuan dibanding laki-laki. Hal ini diduga terjadi karena uretra perempuan lebih pendek, sehinga mereka lebih mudah mengalami infeksi. Selain itu, juga karena perempuan mempunyai jumlah glomerulus yang lebih sedikit. Penelitian ini juga menunjukkan adanya 
korelasi negatif yang tidak signifikan secara statistik antara kadar urea dengan homocitruline pada pasien gagal ginjal terminal. Temuan ini berbeda dengan

\section{DAFTAR RUJUKAN}

1. National Kidney Foundation. KDOQI Clinical Practice Guidelines for Chronic Kidney Disease: Evaluation, Classification, and Stratification, 2000. Available from http://www2.kidney.org/professionals/KDOQI/ guidelines_ckd/toc.htm

2. Jaisson S, Pietrement C, Gillery $P$. Carbamilation Derivat Product: Bioactive compound and Potential Biomarker in Chronic Renal Failure and Atherosclerosis. Clin Chem. 2011:57(11);1499-1505.

3. Schindhelm RK, van der Zwan LP, Teerlink T, and Scheffer PG. Myeloperoksidase: A Useful Biomarker for Cardiovascular Disease Risk Stratification? Clin Chem. 2009:55(8); 146270.

4. Krane V, Wanner C. Cardiovascular Diseases and Predisposing Factor in Chronic Renal Failure. J Clin Basic Cardiol. 2001:4(2);97100.

5. Holzer M, Gauster M, Pfeifer T, Wadsack C, Fauler G, Stiegler $P$, et al. Protein Carbamylation Renders High Density Lipoprotein Dysfunctional. Antioxid Redox Signal 2011:14(12);1-10.

6. Kalim S, Tamez H, Wenger J, Ankers E, Trottier CA, Defario JJ, et al. Carbamylation of Serum Albumin and Erythropoetin Resistance in End Stage Kidney Disease, Clin J Am Soc Nephrol. 2013:8;1927-34

7. Ok E, Basnakian AG, Apostolov EO, Barry YM, Shah SV. Carbamylated low-density lipoprotein induces death of endhotelial cells: A link to atherosclerosis in patient with kidney disease. Kidney Int 2005:68;173-8.

8. Balion CM, Draisey TL, Thibert RJ. Carbamylated Hemoglobin and Carbamylated Plasma Protein in Hemodialyzed patient. Kidney Int. 1998:53;488-95

9. Koeth RA, Kalantar-Zadeh K, Wang Z, Fu X, Tang W, Hazen SL. Protein Carbamilation Predict Mortality in ESRD. Am Soc Nephrol. 2013:24;853-61. beberapa hasil penelitian sebelumnya. Perbedaan ini kemungkinan disebabkan karena kadar $\mathrm{pH}$ atau asam amino, yang dalam penelitian ini tidak diukur.

10. Saat NZ, Kamaralzaman S, Shaari N, Yusoff FZ. Association Between Dialysis Dose and Biochemical Blood Parameters. Sains Malaysiana. 2011:40(5);467-473.

11. Saryono, Handoyo. Kadar Ureum dan Kreatinin Darah pada Pasien yang Menjalani Terapi Hemodialisis di Rumah Sakit Umum Margono Soekarjo Purwokerto, 2011.

12. Sukandar E. Gagal Ginjal Kronik dan Terminal, dalam Nefrologi Klinik, edisi III, Pusat Informasi IImiah Bagian IImu Penyakit Dalam FK UNPAD/RS. Dr. Hasan Sadikin, Bandung, 2006,465-521

13. Silbiger S, Neugarten J. Gender and Human Chronic Renal disease. Gend Med. 2008:5; 53-9

14. Chijioke A, Makusidi AM, Shittu AO, Sanni MA, Biliaminu SA, Abdul_Rahman MB, et al. Pattern Of Lipid Profile In Dialysis Naïve Chronic Kidney Disease Patients From Ilorin, Nigeria. Internet J Nephrol. 2010;6:6.

15. Wilson LM. Gagal Ginjal Kronik, dalam Patofisiologi Konsep Klinis Proses-Proses Penyakit, edisi 6, Editor edisi Bahasa Indonesia Hartanto $\mathrm{H}$, Susi $\mathrm{N}$, Wulansari $\mathrm{P}$, dan Mahanani DA. EGC:Jakarta;2003:912990.

16. Wang Z, Nicholls SJ, Rodriguez EJ, Kummu O, Ho"rkko , Barnard J., et al. Protein carbamylation links inflammation, smoking, uremia and atherogenesis. Nat Med 2007:13 (10);1176-84

17. Pietrement C, Gorisse L, Jaisson L, Gillery P. Chronic Increase of Urea Lead to Carbamylated Protein Accumulation in Tissue in a Mouse of CKD. Plosone 2013: 8(12):1-10.

18. Righetti PG. Real and imaginary artefacts in proteome analysis via two-dimensional maps. J Chromatogr. 2006;841:14-22.

19. Medical Press. Study Identifies New Risk Factor for Heart Diseasae Among Kidney Dialysis Patient. 2013, diunduh dari Medicalpress.com tanggal 27 Januari 2014. 